\title{
Transpersonal caring model in home-Care nursing for children with special care needs
}

\author{
Luana Tonin*1, Maria R. Lacerda ${ }^{1}$, Luciane Favero ${ }^{2}$, Jaqueline D. Nascimento ${ }^{1}$, Patricia K. Rocha ${ }^{3}$, Nara M.O. \\ Girardon-Perlini ${ }^{4}$ \\ ${ }^{1}$ Post-Graduation Program in Nursing, Federal University of Paraná, Curitiba, Brazil \\ ${ }^{2}$ Department of Nursing, Positivo University, Curitiba, Brazil \\ ${ }^{3}$ Post-Graduation Program in Nursing, Federal University of Santa Catarina, Florianopolis, Brazil \\ ${ }^{4}$ Post-Graduation Program in Nursing, Federal University of Santa Maria, Santa Maria, Brazil
}

Received: June 3, 2018

DOI: $10.5430 /$ jnep.v9n1p105
Accepted: September 16, $2018 \quad$ Online Published: September 20, 2018

URL: https://doi.org/10.5430/jnep.v9n1p105

\begin{abstract}
The study was theoretically and philosophically guided by the Theory of Human Care, entailing the use of the Elements of the Clinical Caritas Process, having humanistic assumptions based on Home Care, and being operationalized by the following action steps: Initial Contact, Approaching, Transpersonal Encounter and Separation. It aimed to apply the Transpersonal Care Model in Home Care Nursing to children with special healthcare needs. Qualitative care-research (intervention), developed by means of five components: approaching the studied object; encounter with the cared-researched being; connections between theory and practice; separation from the researcher-caregiver being to the cared-researched being, and analysis of what has been learned by means of the General Analytical Strategy - Relying on theoretical propositions - and Specific Analytical Technique - Pattern Combination. The key results from the development of each one of the steps are, as follows: assumptions were applied 537 times, 322 usages of the Clinical Caritas Process, and 467 care needs were met by means of the model. The model potentialities were identified, understanding that it was built for the population at home care, thus enabling relation development, meeting their needs, and supporting nurses to foster care delivery.
\end{abstract}

Key Words: Nursing models, Home care nursing, Nursing theory, Child health, Nursing research, Methodology

\section{INTRODUCTION}

Caring Models can be understood as a theoretical framework where interrelationship of concepts, assumptions and caring ways occur. ${ }^{[1,2]}$ It is a composition, entailing nursing concepts (Environment, Nursing, Health, Human Being), and others whenever it is deemed necessary, in addition to assumptions which are strengthened by theoreticalphylosophical background, aiming to guide nursing care. ${ }^{[3-5]}$ In this perspective, in 2013, the Transpersonal Caring
Model to Home Care Nursing (TCMHCN $)^{[5]}$ was developed, grounded in Lacerda's Caring Process. ${ }^{[6]}$ That model is theoretically and philosofically guided by Jean Watson's Theory of Human Caring, ${ }^{[7]}$ carries its own humanistic assumptions and concepts, comprises the use of elements from the Clinical Caritas Process (CCP), ${ }^{[8]}$ and is operationalized by the following action steps: Initial Contact, Approaching, Transpersonal Encounter and Separation, ${ }^{[5]}$ as shown in Figure 1.

\footnotetext{
*Correspondence: Luana Tonin; Email: luanatonin@ @otmail.com; Address: Post-Graduation Program in Nursing, Federal University of Paraná, Curitiba, Brazil.
} 


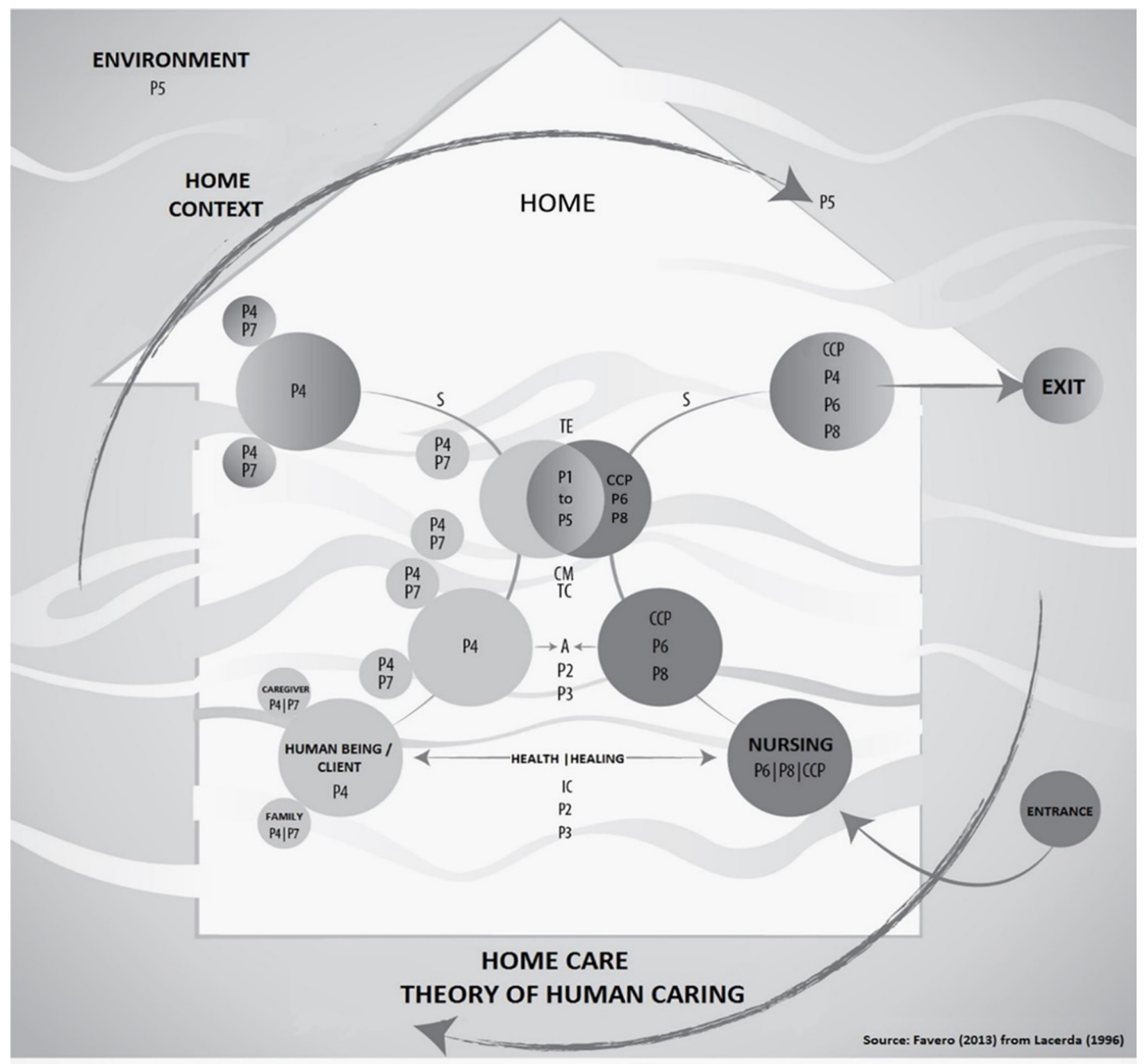

\section{LEGEND: $\widehat{\Lambda}$}

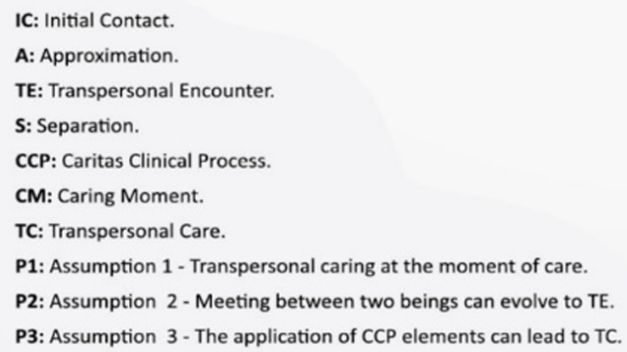

P4: Assumption 4 - TC involves two or more united beings in a single purpose that modify one another physically, mentally, and spiritually and become restored, one carrying a little of the other.

P5: Assumption 5 - The setting and the home context influence the scope of TC. P6: Assumption 6 - Knowledge, empathy, altruism, respect, sensitivity, and the genuine desire to be in a relationship are characteristics of the nurse who works in home care and who hopes to apply the theory of human caring. P7: Assumption 7 - Family /Family caregiver is the fundamental element for effective home care and with the user /human being form the care unit of the nurse. P8: Assumption 8 - Look, listen, touch, be present, available, do not prejudge, assist and other impositions, representing beliefs and customs, lead to TC.

Figure 1. Representative Diagram of the Transpersonal Caring Model in Home Nursing. ${ }^{[5]}$

The TCMHCN can be applied to different populations, worldwide and their demands for specific care. ${ }^{[9,10]}$ among them, children with special healthcare needs $(\mathrm{CSHCN})$ and their families at their homes, due to the increasing number of children suffering from chronic conditions

The CSHCN can be classified according to five main healthcare demands, as follows: Developmental, technological, medication, modified habits and mixed ones (more than one 
type of needs). ${ }^{[9]}$

It proposes not only to potentialize health care, but also this work bridges the existing gap in Home Care and Pediatric Nursing practice and theory towards those children. ${ }^{[11]}$ Therefore, the application of the TCMHCN may colaborate for the appropriation of the theoretical framework on the part of nurses who deliver home care, thus providing them with the tools to apply humanistic caring and, consequently, to identify needs for a probable Transpersonal Nursing Caring for the CSHCN and their families.

Thus, meeting caring needs in view of the Theory of Human Caring is considered, which is understood as something essential or perceived as inevitable by the cared being. ${ }^{[12]}$ In such framework, the satisfaction of human needs is understood as the utmost condition to reach optimal health status, and they should work in an interdependent, integrated way, in a perspective of holistic care. ${ }^{[13]}$

Under such understanding, the theorist grounds in a hierarchy of needs whose lower-order ones comprise physiological, biophysical and psychophysical needs, and the higher-order ones correspond to psychosocial, achievement, integrative and growth-seeking needs in order to reach transcendence and healing. ${ }^{[12,13]}$

Being aware of that reality, and acknowledging Nursing importance to get appropriated of such theoretical frames into practice, the guiding question in this study is: How is the Transpersonal Caring Model applied in Home Care Nursing to CSHCN? And how can it be checked if those caring needs can be met? In order to answer such a question, a goal was outlined: to apply the Transpersonal Caring Model in Home Care Nursing to CSHCN.

\section{MAterials AND Methods}

It is a qualitative research study, developed by means of Care Research (Intervention Research). The five essential components proposed by the Care-Research method were contemplated: the studied object; encounter with the researched-cared being; connections between theory and practice; separation between the researcher-caring being and the researched-cared being; analysis of what was apprehended. ${ }^{[14]}$

The studied object was approached by means of the literature review regarding the theme, the theoretical framework of Jean Watson's Theory of Human Caring, and the elaboration of instruments for data colletion. ${ }^{[8]}$ The encounter with the researched-cared being took place at the homes of CSHCN and their families belonging to the coverage area of a Home Health Care Service located in a municipality in Southern

Published by Sciedu Press
Brazil.

As criteria of inclusion, were considered: CSHCN, ages between zero and 12 incomplete years, disregarding the pathology or classification by healthcare needs, who were having home care by the aforementioned healthcare service. Family caregivers and their legal guardians, ages over 18 years, also participated.

In the step of connections between theory and practice, the TCMHCN was carried out and, concomitantly, the data collection, performed by the head researcher in each step of the research, by means of the caring process records in field diaries. ${ }^{[15]}$ Eight CSHCN, and 12 family caregivers participated in the study, totaling 77 hours and five minutes of care. Seven CSHCN featured mixed needs (technologydependent in order to survive and psychomotor developmental disorders), one child was classified and cared as featuring modified-habit needs.

It was mediated by the theoretical guidance of the model, with the assumptions formerly established, as shown in Figure 1. And as for the Elements of the $\mathrm{CCP},{ }^{[8]}$ this step was carried between October 2016 and May 2017.

The separation of the researcher-caring being took place by the end of the established relationship, which was prepared along the research, as follows: Evolvement of the relationship towards the Transpersonal Caring, hospitalizations, professional detachment as prior preparation for care delivery, or for the impossibility to achieve Transpersonal Caring.

As for the analysis of the apprehended, which consists of the final step, when all the information gathered during the step of model application is analyzed in the perspective of the theoretical framework adopted, and the selected analysis technique. ${ }^{[14]}$ In this study, the "General Analytical Strategy - Relying on Theoretical Propositions" was used, and the "Pattern Combination"[16] was adopted as the specific analytical technique, conducted in a way that the research question is answered and the set goal is achieved.

Therefore, after the elaboration of the field diaries with the description of the delivered care, which assumptions and elements of the CCP were used, and the distinction between each one of the TCMHN, the instruments to help the analysis of the field diary were organized, enabling the counting of the number of times that each theoretical element of the model was used, and also the number of times that a certain caring need was met in each step.

In order to ensure ethical behavior during the research process, the guidelines of Resolution 510/2016 of the National Health Council, ${ }^{[17]}$ grounded in the Nuremberg Code (1947), 
Universal Declaration of Human Rights (1948), Declaration of Helsinki (1964 and amendments). The project was approved by the Ethics and Research Board of the Universidade Federal do Paraná and Municipal Secretary of Health, opinion number 1.738.079, September 21st, 2016. Free Informed Consent was obtained from the CSHCN's family caregivers for their participation in the study, and another Consent was obtained from the responsible family members for their own participation.

\section{RESULTS}

The application of the TCMHCN was carried out at the home of each child with his/her family, an average of 10 encounters for each family and child for about one hour.

After the analysis of the apprehended, Tables 1, 2 and 3 show how the assumptions of the TCMHCN were used in each phase of the operationalization, and how these theoretical elements meet CSHCN's care needs, as well as their family members'.

Table 1. Distribution of the use of the assumptions in each step of the TCMHCN

\begin{tabular}{llllll}
\hline $\begin{array}{l}\text { Assumptions of the } \\
\text { TCMHCN }\end{array}$ & Initial Contact & Approaching & $\begin{array}{l}\text { Transpersonal } \\
\text { Encounter }\end{array}$ & Separation & Total \\
\hline Assumption 1 & 0 & 0 & $3.1 \%(\mathrm{n}=17)$ & $0.1 \%(\mathrm{n}=1)$ & $3.3 \%(\mathrm{n}=18)$ \\
Assumption 2 & $3 \%(\mathrm{n}=16)$ & $4.3 \%(\mathrm{n}=23)$ & $1.11 \%(\mathrm{n}=6)$ & 0 & $8.4 \%(\mathrm{n}=45)$ \\
Assumption 3 & $17.5 \%(\mathrm{n}=94)$ & $8.7 \%(\mathrm{n}=47)$ & $3.3 \%(\mathrm{n}=18)$ & $1.11 \%(\mathrm{n}=6)$ & $30.7 \%(\mathrm{n}=165)$ \\
Assumption 4 & $1.3 \%(\mathrm{n}=7)$ & $0.4 \%(\mathrm{n}=2)$ & $4 \%(\mathrm{n}=22)$ & $0.5 \%(\mathrm{n}=3)$ & $6.3 \%(\mathrm{n}=34)$ \\
Assumption 5 & $8.5 \%(\mathrm{n}=46)$ & $1.3 \%(\mathrm{n}=7)$ & $0.7 \%(\mathrm{n}=4)$ & $0.18 \%(\mathrm{n}=1)$ & $10.8 \%(\mathrm{n}=58)$ \\
Assumption 6 & $7 \%(\mathrm{n}=38)$ & $4 \%(\mathrm{n}=22)$ & $1.5 \%(\mathrm{n}=8)$ & $0.4 \%(\mathrm{n}=2)$ & $13 \%(\mathrm{n}=70)$ \\
Assumption 7 & $8.2 \%(\mathrm{n}=44)$ & $2 \%(\mathrm{n}=11)$ & $1.6 \%(\mathrm{n}=9)$ & $0.9 \%(\mathrm{n}=5)$ & $12.8 \%(\mathrm{n}=69)$ \\
Assumption 8 & $8.2 \%(\mathrm{n}=44)$ & $4.4 \%(\mathrm{n}=24)$ & $1.4 \%(\mathrm{n}=8)$ & $0.4 \%(\mathrm{n}=2)$ & $14.5 \%(\mathrm{n}=78)$ \\
Total & $53.8 \%(\mathrm{n}=289)$ & $25.3 \%(\mathrm{n}=136)$ & $17.1 \%(\mathrm{n}=92)$ & $3.7 \%(\mathrm{n}=20)$ & $100 \%(\mathrm{n}=537)$ \\
\hline
\end{tabular}

The 8 assumptions of the TCMHCN were used 537 times $(100 \%)$ in 77 hours and five minutes of caring. Assumption 3 was used the most, as it guides the professional to use the CCP Elements, and grounds Transpersonal Caring performance. The least used assumption was number 1 with $3.3 \%(\mathrm{n}=18)$, as it is intrinsically related to Transpersonal Caring. That assumption, as proposed by the TCMHCN and validated in the findings, shows that the transpersonal caring needs higher frequency of encounters for bonding, trust, maturity in the relationship, and empathy among nursing professional, child and family.

Verifying the ways to use the CCP Elements during the application of the TCMHCN, in Table 2 was shown the adoption according to the predicted and recommended by assumption 3 of the TCMHN, which states that "the application of the CCP Elements during the steps of Initial Contact, Approaching, Transpersonal Encounter and Separation are able to foster transpersonal caring". [5] Thus, the CCP Elements were used 322 times (100\%) during 77 hours and five minutes of caring.

Table 2. Distribution of the use of the elements of the Clinical Caritas Process in each step of the TCMHCN

\begin{tabular}{llllll}
\hline Elements of the CCP & Initial Contact & Approaching & Transpersonal Encounter & Separation & Total \\
\hline CCP 1 & $6.8 \%(\mathrm{n}=22)$ & $3.4 \%(\mathrm{n}=11)$ & $1.8 \%(\mathrm{n}=6)$ & $0.9 \%(\mathrm{n}=3)$ & $13 \%(\mathrm{n}=42)$ \\
CCP 2 & $2.8 \%(\mathrm{n}=9)$ & $2.4 \%(\mathrm{n}=8)$ & $1.8 \%(\mathrm{n}=6)$ & $0.62 \%(\mathrm{n}=2)$ & $7.7 \%(\mathrm{n}=25)$ \\
CCP 3 & $0.62 \%(\mathrm{n}=2)$ & $0.62 \%(\mathrm{n}=2)$ & $0.9 \%(\mathrm{n}=3)$ & 0 & $2.1 \%(\mathrm{n}=7)$ \\
CCP 4 & $12.1 \%(\mathrm{n}=39)$ & $2.8 \%(\mathrm{n}=9)$ & $1.5 \%(\mathrm{n}=5)$ & $0.3 \%(\mathrm{n}=1)$ & $16.7 \%(\mathrm{n}=54)$ \\
CCP 5 & $4.3 \%(\mathrm{n}=14)$ & $3.1 \%(\mathrm{n}=10)$ & $1.2 \%(\mathrm{n}=4)$ & 0 & $8.6 \%(\mathrm{n}=28)$ \\
CCP 6 & $3.4 \%(\mathrm{n}=11)$ & $2.8 \%(\mathrm{n}=9)$ & $0.62 \%(\mathrm{n}=2)$ & 0 & $6.8(\mathrm{n}=22)$ \\
CCP 7 & $8 \%(\mathrm{n}=26)$ & $4 \%(\mathrm{n}=13)$ & $0.62 \%(\mathrm{n}=2)$ & 0 & $12.7(\mathrm{n}=41)$ \\
CCP 8 & $1.5 \%(\mathrm{n}=5)$ & $3.4 \%(\mathrm{n}=11)$ & $1.2 \%(\mathrm{n}=4)$ & 0 & $6.2 \%(\mathrm{n}=20)$ \\
CCP 9 & $15 \%(\mathrm{n}=48)$ & $3.4 \%(\mathrm{n}=11)$ & $2.8 \%(\mathrm{n}=7)$ & $0.3 \%(\mathrm{n}=1)$ & $21 \%(\mathrm{n}=67)$ \\
CCP 10 & $0.3 \%(\mathrm{n}=1)$ & $0.3 \%(\mathrm{n}=1)$ & $3.1 \%(\mathrm{n}=10)$ & $1.2 \%(\mathrm{n}=4)$ & $5 \%(\mathrm{n}=16)$ \\
Total & $55 \%(\mathrm{n}=177)$ & $26.4 \%(\mathrm{n}=85)$ & $15.2 \%(\mathrm{n}=49)$ & $3.4 \%(\mathrm{n}=11)$ & $100 \%(\mathrm{n}=322)$ \\
\hline
\end{tabular}


The step of the TCMHCN which used the most CCP Elements was the Initial Contact $21 \%(n=67)$, where CCP Element 9 stood out. ${ }^{[8]}$ It is justified by the fact that such a step entails a lot of discoveries between the caring being and the cared being, the Nurse identifies the involved individuals' caring needs and tries to meet them.

Subsequently, the least used CCP Element was number $10.5 \%(\mathrm{n}=16)$, which can be justified for being the element that drives the Nurse to include the cared being's needs for beliefs, and the higher-order needs, which enable transcendence, the Transpersonal Caring, therefore, the healing among the involved individuals.
During all the application of the TCMHCN to the CSHCN and their families, their caring needs were identified, and tried to be met according to the selected theorist's view for 467 times $(100 \%)$, as shown in Table 3 . The step of the model which featured the greatest number was during the Initial Contact, 64\% $(\mathrm{n}=299)$, therefore, in this step, the need which showed the greatest identification and response was ventilation, $23.1 \%(\mathrm{n}=108)$, attributed as concrete and lower order (biophysical), standing out throughout the use of the model, and having the following characteristics: tracheostomy caring, oxygen therapy, mechanical ventilation, saturation control and aspiration.

Table 3. Caring needs attained during each step of the TCMHCN

\begin{tabular}{llllll}
\hline Caring Needs Attained & Initial Contact & Approaching & Transpersonal Encounter & Separation & Total \\
\hline Food and fluid* & $7.5 \%(\mathrm{n}=35)$ & $0.2 \%(\mathrm{n}=1)$ & 0 & $0.4 \%(\mathrm{n}=2)$ & $8.1 \%(\mathrm{n}=38)$ \\
Elimination* & $9.6 \%(\mathrm{n}=45)$ & $1 \%(\mathrm{n}=5)$ & 0 & $0.2 \%(\mathrm{n}=1)$ & $10.9 \%(\mathrm{n}=51)$ \\
Ventilation* & $23.1(\mathrm{n}=108)$ & $6 \%(\mathrm{n}=28)$ & 0 & $1 \%(\mathrm{n}=5)$ & $30.1 \%(\mathrm{n}=141)$ \\
Activity-inactivity* & $14 \%(\mathrm{n}=65)$ & $3.2 \%(\mathrm{n}=15)$ & 0 & $0.2 \%(\mathrm{n}=1)$ & $17.4 \%(\mathrm{n}=81)$ \\
Sexuality* & 0 & $0.6 \%(\mathrm{n}=3)$ & 0 & 0 & $0.6 \%(\mathrm{n}=3)$ \\
Achievement** & $5 \%(\mathrm{n}=23)$ & $8.1 \%(\mathrm{n}=38)$ & $1.7 \%(\mathrm{n}=8)$ & 0 & $14.8 \%(\mathrm{n}=69)$ \\
Affiliation** & $5 \%(\mathrm{n}=23)$ & $3.8 \%(\mathrm{n}=18)$ & $0.6 \%(\mathrm{n}=3)$ & $0.6 \%(\mathrm{n}=3)$ & $10 \%(\mathrm{n}=47)$ \\
Self-actualization** & 0 & $0.8 \%(\mathrm{n}=4)$ & $6.4 \%(\mathrm{n}=30)$ & $0.6 \%(\mathrm{n}=3)$ & $7.9 \%(\mathrm{n}=37)$ \\
Total & $64 \%(\mathrm{n}=299)$ & $24 \%(\mathrm{n}=112)$ & $8.8 \%(\mathrm{n}=41)$ & $3.2 \%(\mathrm{n}=15)$ & $100 \%(\mathrm{n}=467)$ \\
\hline
\end{tabular}

*Lower-order Needs (biophysical and psychophysical); **Higher-order Needs (psychosocial and inter-intrapersonal).

In the Approaching step of the model, the need which stood out was achievement, $8.1 \%(\mathrm{n}=38)$, recognized as higherorder (psychosocial). Distinguished as an integrating need, it reflects this step itself, represented by several ways of communication, that is, when the Nurses will voice their probable doubts, actively understand and share experiences.

In the Transpersonal Encounter, the outstanding need was self-actualization, $1.7 \%(\mathrm{n}=8)$, higher-order, abstract and intra-interpersonal. It pursues transcendence and, consequently, healing. It was expressed several times by a period of joy, hope for the child's improvement and recovery, when identification and consideration of the involved individuals' needs for beliefs, involvement in spiritual issues, satisfaction of caring actions, feeling of gratitude, affection and love by the involved individuals in the relationship occurred.

The last step of the model, Separation, featured the least number of needs attained, as well as the assumptions and CCP Elements used, as at the end of the established relation, when the involved individuals are free from the established bonding, all of them are prepared to carry on with their lives, strengthened by the former steps.

\section{Discussion}

The results obtained with the application of the TCMHCN to the CSHCN enable us to identify that the aforementioned model is reliable for use, as it meets this population's care needs.

When compared to a study applying the same model, even though the patient was undergoing post-stem-cell transplantation, ${ }^{[18]}$ similarities are found in the effectiveness of the results. It was identified that the thought was focused on the other and on the self, facing a possibly vulnerable human condition, which can be potentially developed, the caring being takes the responsibility, with a deep and reflexive value, for each one of the proposed ways of caring manifestations. ${ }^{[18]}$

From the complexity and importance of the evolved caring by means of the application of the TCMHCN, it is deemed necessary to point out the urgency in the use of caring models to nursing practice in order to meet caring needs.

Thus, models can be considered the essence of Nursing, and include the dynamics of the being, to achieve and develop. ${ }^{[19,20]}$ They provide a methodology of articulation of thoughts, and can still be identified as a bridge between the- 
ory and practice, by embodying a large guide of dialogue among several settings of application by means of assumptions and theoretical landmarks. ${ }^{[21]}$

Regarding the use of the assumptions to this specific population, they show that they help nurses deliver home care, and they serve as theoretical background. According to the exposed, when assumptions are evidenced, they become propositions, statements that can be defined as claims about a reality, relations between events or actions, and may develop to characterize the domain of a concept. ${ }^{[22]}$

In addition, the theoretical background of the TCMHCN is provided by the Elements of the Clinical Caritas Process, once the support of these ten elements is necessary in order to define, in a better way, nurses' social, ethical responsibilities and explain the implications of human caring, as they deepen into philosophical, transpersonal, ethical, spiritual and metaphysical aspects, ${ }^{[23]}$ and guide the professional to achieve transpersonal caring.

These theoretical foundations, evolved from inner model structures, generate greater caring expertise, and better quality of life for the cared being. A virtuous circle is conceived between greater competence and social support, in such a way that the more skillful the caring being is, the higher the gains for the cared being. ${ }^{[24]}$ Consequently, by using models grounded in the Theory of Human Caring, nurses can be trained to become competent caregivers. ${ }^{[25]}$

Moreover, the current research evidences that the elements and theoretical foundations from the TCMHCN feature as tools strengthened to assist CSHCN, and this can be demonstrated by the number of times that enabled the identification and attainment of care needs (467 times).

Despite the hierarchical way that they are referred to (lower order and higher order), all must be valued and considered, that is, the concrete ones (biological, functional, survival and lower-order), as well as the abstract ones (psychosocial, inter-intrapersonal, affiliative and higher order). ${ }^{[12]}$

Thus, a need can never be completely separated from the other, they operate dynamically as a whole, are equally important to all quality Nursing care. ${ }^{[13]}$

This theorist explains that this distinction between lowerorder needs and high-order ones aimed to recognize selfactualization (healing) as the ultimate human need. "I consider that the highest level of health is a subjective state of awareness recognition of your own needs, behaviors, wishes and motivations, and the realization of control over the actions". ${ }^{[12]}$

For each step of the exposed model, needs were met and appeared in greater frequency at certain steps, which can be correlated with the own characteristics of the TCMHCN, as in the first steps (Initial Contact and Approaching), the needs that stood out were lower-order ones (biological), and until they were not attained, it was hard to move up to the attainment of higher-order ones (self-realization), so that the Transpersonal Encounter eventually occurred.

Therefore, by applying the Theory of Human Caring or any caring models alike, apart from experiencing the transcendence within those settings, that is, the authentic presence, spirituality, love, kindness, it is believed to experience miracles and learning while professional tasks are being performed. ${ }^{[26]}$ Thus, the positive consequences for the cared being when Nursing professionals are using the Theory of Human Caring, are implied in several studies. ${ }^{[27-29]}$

Study results emphasize and show that the use of the Theory of Human Caring can be greatly beneficial for Nursing managers and educators, in addition to caring models based on it, ${ }^{[25]}$ once it points and contributes to the factors that should be taken into account to enhance satisfaction, responses to the needs of the cared being, and those of the professional at his/her workplace. ${ }^{[27-29]}$

Thus, by appropriating from the grand Theories, MiddleRange Theories and Caring Models, Nursing may take their position on disciplinary knowledge, and this collective construction will lead to the profession identity, as well as to the visibility of Nursing knowledge. In addition, it responds to the care delivery that people need. ${ }^{[30]}$

\section{Limitations and directions for future research}

This study was limited to a specific population of CSHCN and their families, therefore, new replications are demanded with different participants at different settings. Moreover, new research studies may address the evaluation process of caring models, such as the TCMHCN, and still verify the possibility of enhancing the assumptions of this study to prospective theoretical propositions, as well as to the development of a Middle-Range Theory to Home Care Nursing.

\section{Conclusions}

The potentiality demonstrated by applying the TCMHCNA is supported by the obtained results, which evidence the effectiveness of the elements and theoretical foundations of the model to assist CSHCN as well as their families'.

Another outstanding factor refers to the fact that the TCMHNA was built for the population who experiences home care. Thus, this model considers the specificities and singularities of each setting, and guides the applicability of the Theory of Human Caring, thus being important for 
nurses' professional practice, promoting daily applicability of the transpersonal care.

Concluding, it is believed that the research process and the obtained results reassure the TCMHCNA, and its efficiency to CSHCN and their families, as well as to Home Care Nursing. It is an instrument which guides nursing job, systematizes and strengthens human healthcare.

\section{ACKNOWLEDGeMENTS}

We thank the National Council for Scientific and Technological Development in Brazil to grant a scholarship to one of the authors of this manuscript.

\section{CONFlicts of InTEREST Disclosure}

The authors declare no conflict of interests.

\section{REFERENCES}

[1] Mccrae N. Whither nursing models? The value of nursing theory in the context of evidence-based practice and multidisciplinary health care. J Adv Nurs. 2012; 68 (1): 222-229. PMid:21906131 https://doi.org/10.1111/j.1365-2648.2011.05821.x

[2] Fawcett J. Analysis and evaluation of Contemporary Nursing Knowledge. Nursing Models and theories. Philadelphia: F.A. Davis; 2012. $480 \mathrm{p}$.

[3] Mcewen M, Wills EM. Theoretical basis for nursing. Philadelphia: Lippincott Williams \& Wilkins. 2017. 592 p.

[4] Rocha PK, Prado ML. Modelo de Cuidado ¿Qué es y como elaborarlo? Index Enferm. 2008; 17(2): 128-132.

[5] Favero L. Construção de um Modelo de Cuidado Transpessoal em Enfermagem Domiciliar a partir do Processo de Cuidar de Lacerda [thesis]. [Curitiba (PR)]: Universidade Federal do Paraná; 2013. 173 p. Available from: http://www.ppgenf .ufpr.br/TeseLuciane Favero.pdf

[6] Lacerda MR. Cuidado Transpessoal de Enfermagem no contexto domiciliar. [dissertation]. [Florianopólis (SC)]: Universidade Federal de Santa Catarina; 1996. 107 p.

[7] Watson J. Human caring science: a theory of nursing. 2nd ed. Ontario: Jones \& Bartlett Learning; 2012. 122 p.

[8] Tonin L, Nascimento JDD, Lacerda MR, et al. Guide to deliver the elements of the Clinical Caritas Process. Esc. Anna Nery R. Enferm.-Bra. [Internet]. 2017 [cited 2017 Sep 08]; 21(4): e20170034. Available from: http://www.scielo.br/scielo.php?pid=S14148145 $2017000400220 \&$ script $=$ sci_arttext\&tlng $=$ ptId $:-891716$

[9] Alves GV, de Oliveira Lomba G, Barbosa TA, et al. Children with special health needs of a municipality of minas gerais: a descriptive study. R. Enferm. Cent. O. Min. 2014; 3(4):1310-1321. Available from: http://www.seer.ufsj.edu.br/index .php/recom/article/viewFile/778/768Id:26859http: //dx.doi.org/10.19175/recom.v0i0.778

[10] McPherson M, Arango P, Fox H, et al. A new definition of children with special health care needs. Pediatrics. 1998; 102(1): 137-41. Available from: https://www.ncbi.nlm.nih.gov/pubmed/97 14637 PMid: 9714637 https://doi.or/10.1542/peds.102.1. 137

[11] Leão DM, Silveira AD, Rosa EDO, et al. Family home care to the child with chronic diseases: an integrative review. Rev Enferm UFPE On Line. 2014; 8(1): 2445-54. Available from: https://periodicos.ufpe.br/revistas/revistaenf ermagem/article/view/9936/1025 https://doi.org/10.5 205/1981-8963-v8i7a9936p2445-2454-2014

[12] Watson J. Nursing: The philosophy and Science of caring. 1 st edition. Boston: Little, Brown Company; 1979. 321 p.
[13] Watson J. Nursing: the philosophy and science of caring. Revised edition. Boulder, Colorado: University Press of Colorado; 2008. 313 p.

[14] Zagonel IPS, Neves EP, Marques KMAP, et al. Pesquisa-cuidado da teoria à prática. In: Lacerda MR, Costenaro RGS editores. Metodologias da Pesquisa para a Enfermagem e Saúde da Teoria à prática. Porto Alegre: Editora Moriá; 2016. 215-242 p.

[15] Sampieri RH, Collado CF, Lucio PB. Metodología de la investigación. Sexta Edición. Editorial Mc Graw Hill. México; 2014. 634 p.

[16] Yin RK. Estudo de caso: planejamento e métodos. $5^{\text {a }}$ ed. Porto Alegre: Bookman; 2015. 290 p.

[17] Brasil. Conselho Nacional de Saúde. Resolução n. ${ }^{\circ}$ 510, de 07 de abril de 2016. Dispõe sobre as normas aplicáveis a pesquisas em Ciências Humanas e Sociais. Diário Oficial da União, Brasília, DF, n 98, 24 maio. 2016; 1: 44-46. Available from: http://conselho.s aude.gov.br/resolucoes/2016/reso510.pdf

[18] Rodrigues JAP, Lacerda MR, Favero L, et al. Model of transpersonal caring in nursing home care according to Favero and Lacerda: case report. Rev Gaúcha Enferm. 2016; 37(3): e58271. Available from: http://seer.ufrgs.br/index.php/RevistaGauchadeEnf ermagem/article/viewFile/58271/38640PMid: 27706444 https://doi.org/10.1590/1983-1447.2016.03.58271

[19] Alarcón Á, Barrera L, Carreño S, et al. Desarrollo de un modelo funcional de cuidado de enfermería en câncer. Invest. educ. Enferm. 2014; 32(2): 206-15. Available from: http: //www.scielo.org.co/scielo.php?pid=\$01205307201400 0200003\&script $=$ sci_arttext\&tlng $=$ es ID $: 1 i l-716999$

[20] Hussey PA, Kennedy MA. Instantiating informatics in nursing practice for integrated patient centred holistic models of care: a discussion paper. J Adv Nurs. 2015; 72(5): 1030-1041. PMid: 26890201 httpS://doi.org/10.1111/jan.12927

[21] Olarte AC. Modelo de cuidado de enfermería al paciente en posoperatorio temprano de revascularización miocárdica. Ciencia Y Enferm. 2016; 22(1): 35-46. https://doi.org/10.4067/S0717-95532 016000100004

[22] Meleis AI. Theoretical nursing: development and progress. 5th ed. Pennsylvania: Lippincott Williams \& Wilkins; 2012. 672p.

[23] Watson J, Brewer B. Caring science research: Criteria, evidence, and measurement. JONA. 2015; 45(5): 235-236. Available from: http://journals. lww.com/jonajournal/Citation/2015 105000/Caring_Science_Research__Criteria,_Evidence ,_and.1.aspx .

[24] Barrera-Ortiz L, Carrillo-González GM, Chaparro-Díaz L, et al Modelo para abordar la carga del cuidado de la enfermedad crónica en Colombia. Orinoquia. 2015; 19(1): 89-99. Available from: http://www.scielo.org.co/scielo.php?script=sc i_arttext\&pid=S0121 -37092015000100008 
[25] Peña RCR. The $3 \mathrm{H}$ Model of Holistic Care in Nursing. PNA. 2016; 86(2): 57-61. Available from: http://www . pna-pjn.com/resea $\mathrm{rch} / 007 /$

[26] Norman V, Rossillo K, Skelton K. Creating healing environments through the Theory of Caring. AORN Jornal. [Internet]. 2016 [cited 2017 Jul 07]; 104 (5): 401-409. Available from: http://www.sciencedirect.com/science/article/ pii/S0001209216306184 PMid: 27793250 https://doi.org/ 10.1016/j.aorn. 2016.09.006

[27] Pajnkihar M, Štiglic G, Vrbnjak D. The concept of Watson's carative factors in nursing and their (dis) harmony with patient satisfaction. Peer J. 2017; 5(1): e2940. Available from: https: //www.ncbi.nlm.nih.gov/pubmed/28194310 PMid: 28194310 https://doi.org/10.7717/peerj .2940

[28] Sit JW, Chan AW, So WK, et al. Promoting Holistic Well-Being in Chronic Stroke Patients Through Leisure Art-Based Creative Engagement. Rehabil Nurs. 2014; 1-10. Available from: https: //www.ncbi.nlm.nih.gov/pubmed/25224721 PMid: 25224721 https://doi.org/10.1002/rnj.177

[29] Ozan YD, Okumuş H. Effects of Nursing Care Based on Watson's Theory of Human Caring on Anxiety, Distress, And Coping, When Infertility Treatment Fails: A Randomized Controlled Trial. JCS. 2017; 6(2): 95-109. Available from: https://www. ncbi.nlm.nih.gov/pubmed/28680864PMid:28680864 https: //doi.org/10.15171/jcs.2017.010

[30] Watson J. Clarifying the discipline of nursing as foundational to development of professional nursing. Texto Contexto Enferm. 2017; 26(4): editorial. Available from: http://www.scielo.br/scielo.php?pid=S010407072017 000400201\&script=sci_arttext\&tlng=es 